\title{
TITLE:
}

\section{A LIST OF FISHES FROM THE TOKARA ISLANDS, KAGOSHIMA PREFECTURE, JAPAN}

$\operatorname{AUTHOR}(S)$ :

Kamohara, Toshiji

\section{CITATION:}

Kamohara, Toshiji. A LIST OF FISHES FROM THE TOKARA ISLANDS, KAGOSHIMA

PREFECTURE, JAPAN. PUBLICATIONS OF THE SETO MARINE BIOLOGICAL LABORATORY 1954, 3(3): 265-299

ISSUE DATE:

1954-05-30

URL:

http://hdl.handle.net/2433/174490

RIGHT: 


\title{
A LIST OF FISHES FROM THE TOKARA ISLANDS, KAGOSHIMA PREFECTURE, JAPAN ${ }^{11}$
}

\author{
TOSHIJI KAMOHARA \\ Biological Laboratory, Liberal Arts Faculty, Kôchi University
}

With 17 Text-figures

During a short tour to the Tokara islands, including the southernmost and northernmost isles, Takarajima and Nakanoshima, Kagoshima Prefecture, in the months of May and June, 1953, I made a small collection of fishes chiefly from the tide pools and partly from the open sea. The collection embraces 124 species. Among them the following 14 species are here recorded for the first time as belonging to the fish-fauna of Japan.

Mugil labiosus Cuvier \& Valenciennes (Mugilidae) (East Indies and southwards)

Cephalopholis argis BLOCH \& SCHNEIDER (Serranidae) (China and southwards)

Plectorhynchus diagrammus (LINNÉ) (Haemulidae) (Philippines and southwards)

Anampses twistii BLEEKER (Labridae) (East Indies and southwards)

Stethojulis trilineata (BLOCH \& SCHNEIDER) (Labridae) (Philippines and southwards)

Halichoeres binotopsis (BLEEKER) (Labridae) (The same distribution)

Halichoeres scapularis (BENNETT) (Labridae) (Philippines)

Pseudojulis trifasciatus M. WEBER (Labridae) (East Indies)

Thysanophrys serratus (Cuvier \& VALENCIENnES) (Platycephalidae) (Ceylon and southwards)

Bothus mancus (BroussoneT) (Pleuronectidae) (India and Hawaii)

Solea heterorhina BLEEKER (Soleidae) (Philippines and southwards)

Tripterygion articeps (JENKINS) (Blenniidae) (Hawaii)

Istiblennius edentulus (BLOCH \& SCHNEIDER) (Blenniidae) (China and southwards)

Istiblennius cyanostigma (BLEEKER) (Blenniidae) (Philippines)

Besides those there are 33 species which have not hitherto been recorded from Japan proper including Tanegashima and Yakushima, although they have been recorded from the region from Amami-Oshima to Formosa, and 4 species belonging to the family Blenniidae could not be identified.

1) Scientific Survey of the Tolara Islands, Report No. 9.

Publ. Seto Mar. Biol. Lab., III (3), 1954. (Article 23) 
The fauna of this district bears close relation to that of Formosa and Philippines, and also to that of Southern Japan. In the main, however, the fauna is tropical, a large proportion of the species being found in Philippines and India. A few of the species of Central Japan extend their range southward to this district. All the drawings are my own work, some of them being drawn from specimens from Prov. Tosa instead of those of the present collection because the latter were too small or multilated.

All the specimens secured are deposited at the Osaka Municipal Natural Science Museum, some of the duplicates being contained at the Biological Laboratory of the Liberal Arts Faculty of Kôchi University.

I present with pleasure my deep obligation to Mr. Yoshitaka Tsursur, head of the Scientific Research Party and chief of the Osaka Municipal Natural Science Museum, and I wish to express my profound sense of gratitude to Dr. Shigeho TANAKA, exprofessor of Tokyo University, for his kind encouragement. I am also greatly indebted to Dr. Itirô Tomiyama, chief of the Misaki Marine Biological Station of Tokyo University, who helped me in the identification of some species of the families Gobiidae and Blenniidae.

The following list consists of the above-mentioned 124 species of my collection and 21 species which were observed, but not collected.

\section{Synodontidae}

Saurida undosquamis (RICHARDSON) Ma-eso Native name: Eso (Takarajima)

Only one specimen, $120 \mathrm{~mm}$ long, was collected during the entire period at Takarajima, although the natives claim this species is rather common around the island.

This species is widely distributed in the regions from Southern Japan to Africa and Australia.

\section{Synodus variegatus (LACÉPÈDE) Aka-eso}

Color yellowish generally. On back and sides 9 dark crossbands, the center of which is paler. Dorsal and caudal with more or less conspicuous series of brown spots.

One specimen, $82 \mathrm{~mm}$ in length, from Takarajima.

This species is widely distributed throughout the Indian and Pacific Oceans. In Japan it ranges as far north as the middle part of Japan.

\section{Congridae}

Conger cinereus RÜPPELL Gin-anago Native name: Tokonko (Takarajima)

Characterized by very small pectorals, uniform coloration on head and body, and a marginal black edge to the vertical fins. Pectoral with a black spot. I do not find any evident differences by which $C$. nystromi JORDAN \& SNYDER can be separated from C. cinereus. 
Rather common, especially the young, about $100 \mathrm{~mm}$ long, in both islands.' Several young from Takarajima. The largest one collected at the same place was slightly over $1,000 \mathrm{~mm}$ long.

The species is distributed throughout the Indian Ocean, from Red Sea and Africa to Australia and Polynesia.

\section{Ophichthyidae}

Myrichthys maculosus (CUVIER) (Fig. 1) Goishi-umihebi Native name: Umihebi (Takarajima)

M. aki TANAKA

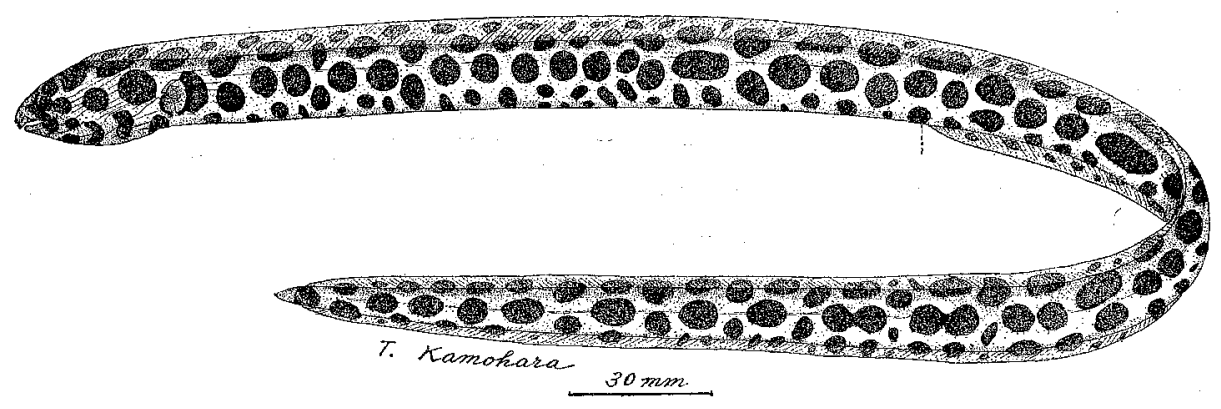

Fig. 1. Myrichthys maculosus (CUVIER).

Color yellowish white, with 3 alternating series of brown, round spots, the middle series the largest, the upper and lower series partly extending onto the fins.

Three specimens, $180-270 \mathrm{~mm}$ in length, from Takarajima.

This species is distributed throughout the Indian and Pacific Oceans, from Red Sea and Madagascar to Hawaii. In Japan it ranges as far north as Prov. Kii.

\section{Muraenidae}

The natives are quite confused over names for most of the species of this family and although they know a great number of names for moray eels, they are often uncertain about using them correctly.

Echidna zebra (SHAw) Zebura-utsubo Native name: Iso-habu (Takarajima)

Tail about twice in head and trunk taken together. Color blackish brown, with about 40 white, black-edged narrow ring-like markings.

Two specimens, about $800 \mathrm{~mm}$ long, from Takarajima. The natives fear this moray eel more than all others and kill them whenever possible, whether they want to eat them or not. Actually this eel may be more abundant than the collections indicated.

This species widely ranges in the Indian and Pacific Oceans, from Africa to Samoa. It has been recorded from Okinawa. 
E. nebulosa ( $\mathrm{AHL}$ ) Kumo-utsubo Native name: Kidaka (Takarajima)

Color yellowish, with numerous fine vermiculated lines or small spots, and two series of large, reticulated black spots, the upper along the back and the lower along the lower half of body.

Two specimens, about $200 \mathrm{~mm}$ long, from Takarajima.

The species is widely distributed in tropical regions in the Pacific and Indian Oceans, from Africa to Polynesia. It has been recorded from Okinawa.

Gymnothorax pictus (AHL) Ase-utsubo Native name: Kidaka (Takarajima)

Color pattern consists of black speckles or tiny black spots on a white background. In specimens $100 \mathrm{~mm}$ long the spots on the body occur in 4-6 irregular rows along body; in specimens $150-200 \mathrm{~mm}$ long the spots have pale centers; in the large specimens the body becomes speckled with tiny black spots.

Rather common, especially the young $100-200 \mathrm{~mm}$ long, in both islands. Two large specimens, 470 and $500 \mathrm{~mm}$ long respectively, from Takarajima.

The species is widely distributed in the regions from Africa to Australia and Mexico. It was also found in Japan (Kii and southwards).

G. petelli (BLEEKER) Kurakake-utsubo Native name: Oki-dakame (Takarajima)

Color brown, with about 20 dark crossbands, which are larger than the interspaces between them. The first band on snout, the third through origin of dorsal. It is easily recognizable by the dark crossbands.

One specimen, about $500 \mathrm{~mm}$ in length, from Takarajima.

It is known in the regions from Okinawa to the East Indies, Samoa and Hawaii. G. meleagris (SHAw \& NoDDER) (Fig. 2) Hanabi-utsubo Native name: Kuro-kidaka (Takarajima)

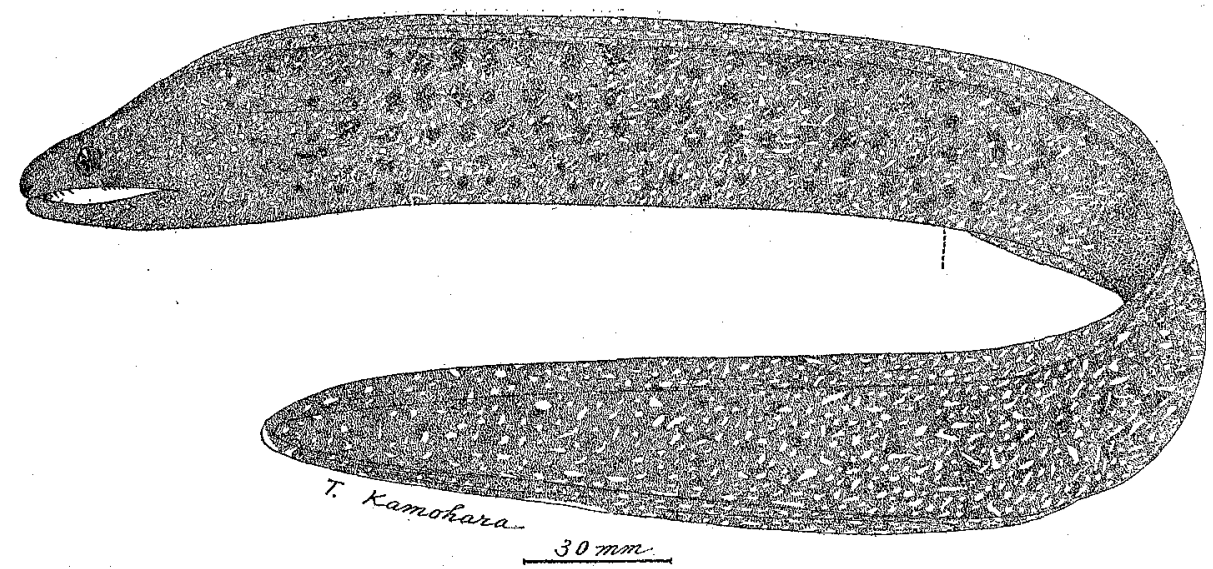

Fig. 2. Gymnothorax meleagris (SHAW \& NODDER). 
Color purplish brown, scattered with small white spots smaller than interspaces. Besides, some five longitudinal rows of black blotches as large as pupil arranged somewhat irregularly overlie the above-mentioned marking on the body. Dr. TaNaka (1908) has indicated this species under the name G. wakanourae, but I know of no evident characters to separate it from G. meleagris.

Two specimens, about $400 \mathrm{~mm}$ long, from Takarajima.

The species is distributed in the regions from Southern Japan to the East Indies, Samoa and Hawaii. In Japan it ranges as far north as Prov. Kii.

G. flavomarginafus (RÜPPELL) Goma-utsubo Native name: Aburame (Takarajima)

Color yellowish, densely covered with blackish spots; these spots may fuse into larger irregular patches, in which case only an yellowish network from the groundcolor is left. Vertical fins narrowly margined with white posteriorly. Gill-openings in a dark brown patch.

Four specimens, $160-240 \mathrm{~mm}$ long, from Takarajima.

The species is widely distributed throughout the Indian Ocean, from Africa to New Guinea. It was also found in Riu Kiu.

G. undulatus (LACËPÉDE) Nami-utsubo Native name: Shiro-kidaka (Takarajima)

Color brownish, speckled, spotted and reticulated with white. Anal broadly margined with white.

One specimen, $170 \mathrm{~mm}$ in length, from Takarajima.

This species is known in the regions from Riu Kiu to the East Indies, New Guinea, Samoa and Hawaii. I have recorded it from Prov. Tosa.

\section{Syngnathidae}

\section{Corythroichthys quinquarius SNYDER Ganten-ishiyōji}

Color yellowish brown; sides of body with very small, pearly ocelli in quinqunx order, each with a brown dot at the the center.

Three specimens, about $95 \mathrm{~mm}$ in length, from Takarajima.

Hitherto known only from Tanegashima.

\section{Microphis extensus SNyder Hibashi-yōji}

Two strongly denticulated ridges extend from snout to interorbital space. Color purplish brown; caudal dark reddish brown, with bright orange spots.

One specimen, $61 \mathrm{~mm}$ long, from Nakanoshima.

Hitherto known only from Naha, Okinawa.

\section{Fistulariidae}

Fistularia serrata CuviEr Ao-yagara Native name: Bō-io or Fügushi (Nakanoshima) Rather common, but no specimens were collected. 
The species is distributed in the regions from the middle part of Japan to the East Indies, New Guinea and Hawaii.

\section{Belonidae}

Tylosurus anastomella (Cuvier \& Valencienses) Datsu Native name: Nagasai (Nakanoshima)

Rather common. Secured for food with hook and line; not collected.

The species is distributed in the regions from Hokkaido and Korea to Southern China.

\section{Exocoetidae}

Cypselurus agoo (Temminck \& Schleger) Tobi-uo Native name: Tobi-uo (both islands)

Common in both islands. One specimen, $300 \mathrm{~mm}$ long, from Nakanoshima. The natives are familiar with this species and well aware where they occur around the islands. This is an important food fish for the natives and is taken by drift-nets.

It is known in the regions from Korea to Formosa and reaches Southern Japan. C. poecilopterus (Cuvier \& VALENCIENNES) Aya-tobi-uo Native name:Tobi-uo (both islands)

Rather common in both islands. One specimen, $220 \mathrm{~mm}$ long, from Nakanoshima.

The species is widely distributed in the regions from Hokkaido and Fuzan to China, Melanesia and Polynesia.

\section{Atherinidae}

Atherion elymus JoRdan \& STARKS (Fig. 3) Mugi-iwashi Native name: Zako or Ara-zako (Takarajima)

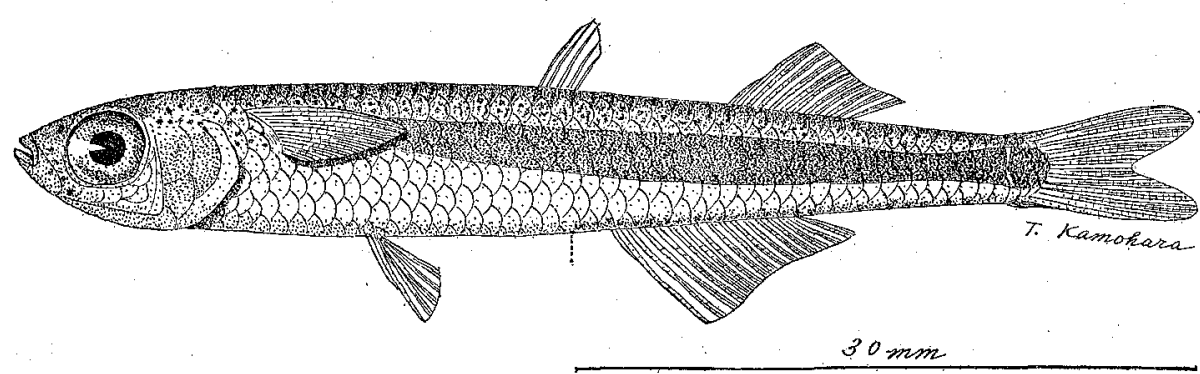

Fig. 3. Atherion elymus JORDAN \& STARKS.

Common in both islands. Occurs in schools in tide pools. Many specimens, about $55 \mathrm{~mm}$ long, from both islands. 
Hitherto known in the regions from Prov. Bösh $\bar{u}$ to Prov. Tosa, and my specimens suggest that the species ranges farther southward to Riu Kiu.

\section{Mugilidae}

Mugil cephalus LinNe (Fig. 4) Bora Native name: Bora (both islands)

Several young, $37-82 \mathrm{~mm}$ long, from both islands.

The species is very widely distributed in almost all the waters of the world.

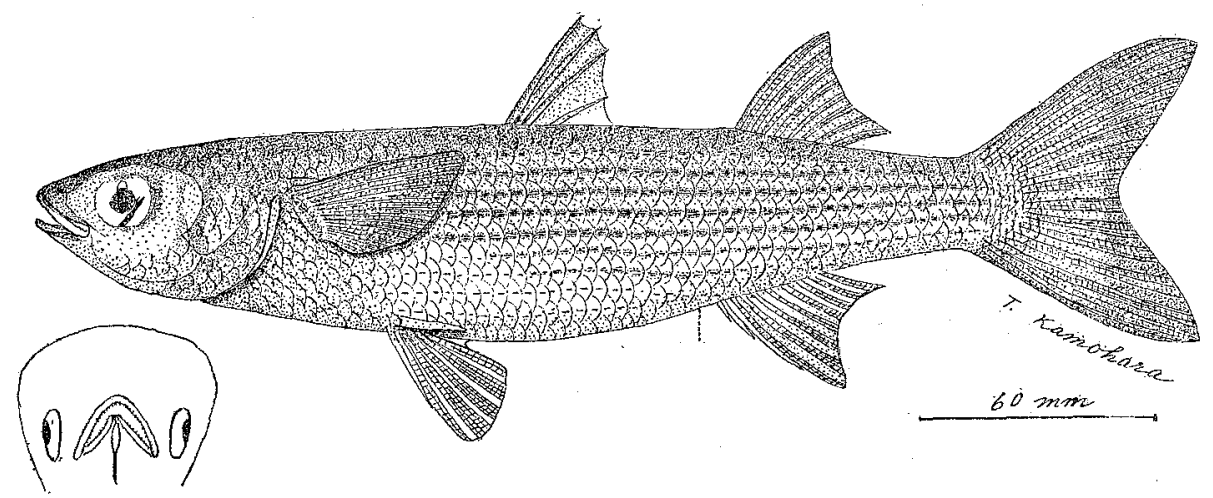

Fig. 4. Mugil cephalus LINNÉ.

M. vaigiensis QUOY \& GAIMARD Munaguro-bora (new Japanese name) Native name: Bora (Takarajima)

D. IV-I, 8; A. III, 8; L. 1. 28. Head very broad and flat; no adipose eyelids; caudal subtruncate. Color dark green, ventrally lighter. Characterized by black pectorals, by a pale caudal, and by the pectoral being shorter than the head.

Several specimens, $70-80 \mathrm{~mm}$ long, from Takarajima. Found in association with Dules taeniurus CUVIER \& VALENCIENNES but not so abundant.

The species is widely distributed throughout the Indian Ocean and the tropical waters of the Pacific Ocean. It was also found in Philippines. Dr. J. T. F. CHEN (1952) has recorded it from Formosa. My specimens suggest that this tropical species ranges to Riu Kiu.

\section{M. engeli BLEEKER Nanyō-bora}

$M$. kelaartii GÜNTHER

D. IV-I, 7; A. III, 9; L. 1. ca 33. Posterior adipose eyelid present. Maxillary hidden when mouth is closed. Pectorals slightly shorter than length of head, reaching 9th lateral scale; caudal peduncle about $\frac{3}{7}$ length of head; caudal deeply concave. Color olivaceous, below silvery.

One specimen, $65 \mathrm{~mm}$ long, from Takarajima. Dr. ŌSHIMA reports as M. kelaartii 
GunTher from Formosa (Ann. Carnegie Mus., vol. XXX, nos. 3-4, 1922). Dr. Fowler (1928) states that there is little doubt that $M$. kelaartii is a synonym of $M$. engeli.

It is known in the regions from Formosa to the East Indies, Samoa and Hawaii.

M. labiosus Cuvier \& VAlEnctennes Mitsukuchi-bora (new Japanese name)

D. IV-I, 8; A. III, 9; L. 1. ca 36. No adipose eyelids. Lower part of upper lip with a shallow groove provided with one series of pointed papillae. Pectorals longer than head; caudal large, emarginate. Color olivaceous above, silvery on sides and below; base of pectoral superiorly. with a very small blackish spot.

One specimen, $143 \mathrm{~mm}$ long, from Nakanoshima. A rare unexpected fish, whose habitat is the East Indies, Red Sea and Melanesia.

Liza macrolepis (SMITH) Uroko-bora (new Japanese name)

D. III-I, 9; A. III, 9; L. 1. 30. Color pale olivaceous, paler below.

One specimen, $140 \mathrm{~mm}$ in length, from Takarajima. The specimen before me differs from the descriptions of several authors in having a smaller number ( 3 instead of 4) of dorsal spines. But judging from the other features it will probably be a variant rather than a distinct species.

The species is known in the regions from Riu Kiu to Africa, Society Islands and Samoa.

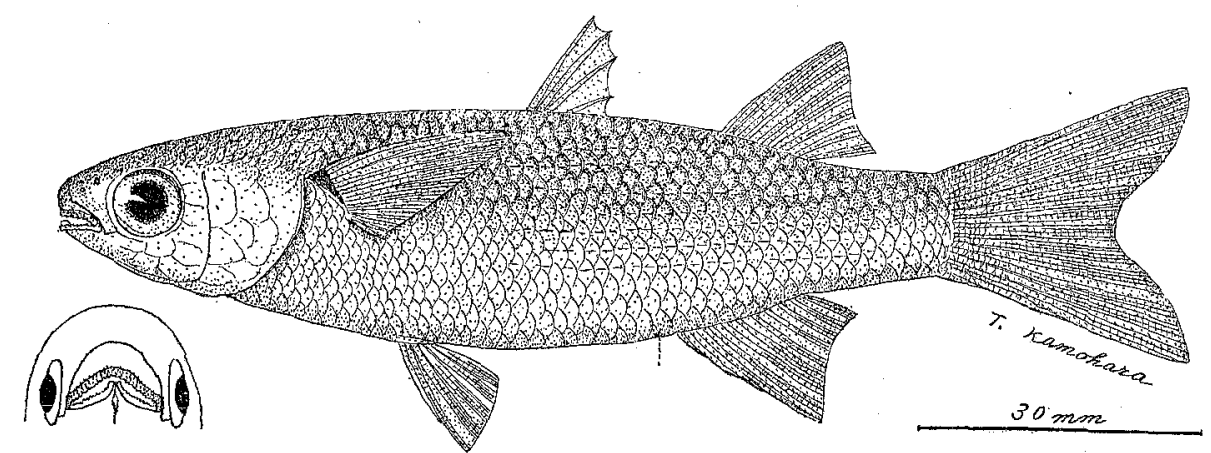

Fig. 5. Crenimugil crenilabis (FORSKÅL).

Crenimugil crenilabis (FORSKÅL) (Fig. 5) Fūrai-bora Native name: Bora (Takarajima)

L. 1. 39. No adipose eyelids. Soft dorsal and anal scaled over most of fins. Upper lip thick, with several series of small fleshy knobs; lower lip crenulated; caudal deeply emarginate. Color greenish, whitish below; base of pectoral superiorly with a small blackish spot.

Several specimens, $80-120 \mathrm{~mm}$ in length, from Takarajima.

This species is widely distributed in the warm waters from the middle part of Japan to Africa. 


\section{Holocentridae}

Holocentrus lacteoguttatus CUVIER \& VALENCIENNES Hoshi-ebisu Native name: Ake-yuo (Nakanoshima)

D. XI, 12; A. IV, 8; L. 1. 45. Color reddish generally, covered with irregular minute dusky dots, and with about 10 longitudinal dark streaks. All the fins yellowish; spinous dorsal with a series of black blotches.

One specimen, $85 \mathrm{~mm}$ long, from Nakanoshima.

This species is distributed in the regions from Riu Kiu to Africa, New Guinea and Polynesia.

H. ruber (FORSKÅL) Ayame-ebisu Native name: Ake-yuo (Nakanoshima)

Color deep red, paler below; snout with 9 longitudinal streaks, of which the four uppermost are blackish and the rest brownish. Dr. TANAKA states that H. spinosissimus TeMminck \& SChlegel is a synonym of this species.

Three specimens, 120-145 mm long, from Nakanoshima.

The species is known in the regions from Prov. Kii to Red Sea and Samoa.

\section{Katsuwonidae}

Katsuwonus pelamys (LINNE) Katsuo

The natives said that this species is common off Takarajima but never collected one during the period we were there.

The species is widely distributed throughout the warm waters of all the world Auxis thazard (LACÉPĖDE) Hirasōda Native name: Subota (Takarajima)

Rather common. Caught with hook and line; not collected.

The species is widely distributed throughout the warm waters of all the world. Euthynnus yaito KIshinoure Suma

Common. Several specimens, about $400 \mathrm{~mm}$ long, were secured with hook and line; not collected.

The species is known in the regions from the middle part of Japan to Korea and Philippines.

\section{Thunnidae}

Thunnus thynnus (LiNNÉ) (Fig. 6) Maguro

During the period at Takarajima a young, about $400 \mathrm{~mm}$ long, was fished with hook and line; not collected. According to the natives this species is rather rarely caught there.

The species is widely distributed throughout the waters of the world, excepting the cold waters. 


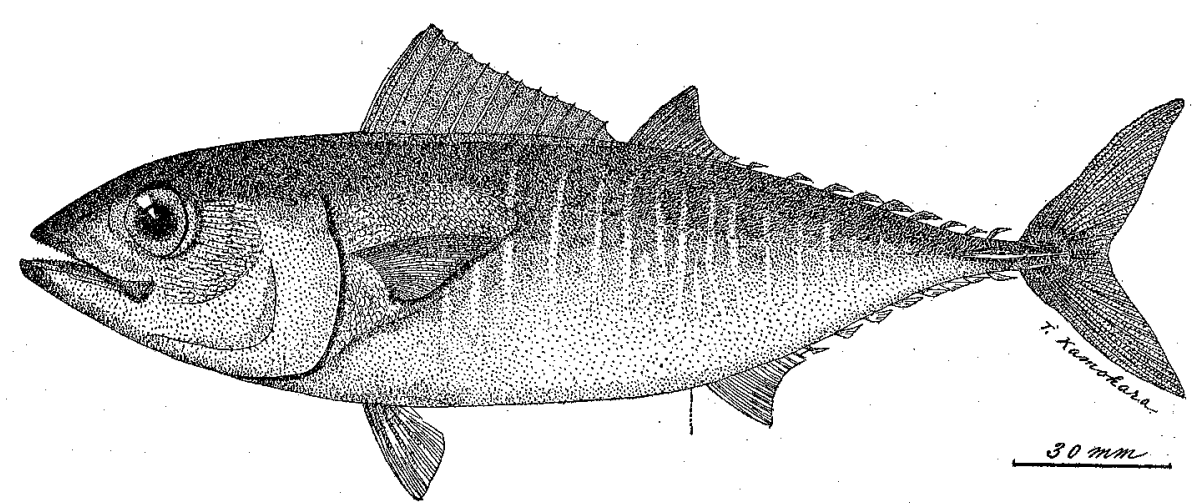

Fig. 6. Thunnus thynnus (LINNE). (Young)

Neothunnus macropterus (TEMMinck \& SchLEgEL) Kihada Native name: Shibi (Takarajima)

Rather common. The natives catch it for food with hook and line called Horobiki and occasionally by spear called Ozuki; not collected.

This species is distributed throughout the warm waters of the Pacific Ocean. In Japan it is found at Hokkaido and southwards.

\section{Cybiidae}

Acanthocybium solandri (Cuvier \& VALENCIENNES) Kamasu-sawara Native name: Sawara (both islands)

Head and body blue above shading to white on belly. Body with about 30 vertical dusky bars.

Common. Several specimens, about $1 \mathrm{~m}$ long, were speared from small boats off Takarajima; not collected. It is one of the main food fishes of the natives.

The species is widely distributed throughout the warm waters of the world.

Sarda chilensis (Cuvier \& VALENCIENNES) Hagatsuo Native name: Hagatsuo (Takarajima)

Rather commonly caught with hook and line; not collected.

The species is known in the regions from the central part of Japan and Fuzan to Africa, Australia and the west coasts of North and South America.

\section{Coryphaenidae}

\section{Coryphaena hippurus LINNÉ Shiira}

Common. The natives catch it with hook and line called Egi. Several large specimens were fished with hook and line from our steamer; not collected. It is one of the main food fishes of the natives. 
This species is widely distributed throughout the warm waters of the world.

\section{Cheilodipteridae}

Apogon novemfasciatus Cuvier \& VALENCIENNES Medama-ishimochi Native name:

Tsurigoro (Takarajima); Isoji (Nakanoshima)

Snout rather pointed, its length three-fourths of eye-diameter; height of praeorbital one-third of eye. Color light reddish brown, whitish below, with 5 blackish longitudinal bands about equal to the interspaces.

Rather common in both islands. Several specimens, $60-105 \mathrm{~mm}$ long, from both islands.

It is known in the regions from Prov. Kii to Africa, Melanesia, Micronesia and Polynesia.

A. endekataenia (BLEEKER) Kosuji-ishimochi

Native names are the same as those of the species mentioned above.

Snout blunt, its length two-thirds of eye-diameter; height of praeorbital equal to half eye. Color light reddish brown, slightly paler below, with 5-6 blackish longitudinal bands. A rather distinct black spot in the lateral line at base of caudal; pectoral axilla blackish.

Rather common in both islands. Several specimens, about $90 \mathrm{~mm}$ long, from both islands.

The species is known in the regions from Southern Japan to Red Sea.

A. erythrinus SNYDER Riū-Kiū-ishimochi

D. VI-I, 10; A. II, 8; L. 1. 25. Head 3.1-3.4 in length without caudal; second dorsal spine 2-2.1; gill-rakers on first arch 3+10-13. Mr. EBINA has proposed the name A. kominatoensis for this species (Journ. Imp. Fish. Inst., vol. XXX, no. 3, 1934, p. 211, fig. 1), but I scarcely find evident characters to separate his specimen from A. erythrinus.

Several specimens, $50-60 \mathrm{~mm}$ long, from both islands.

This species is widely distributed in the regions from Kominato, Chiba Prefecture, to Philippines, Polynesia and Hawaii.

\section{Kuhliidae}

Dules taeniurus Cuvier \& VALEnCIENNEs Gin-yugoi Native name: Hibana (both islands)

This species is one of the most common fishes in both islands and occurs in large schools in tide pools. Length $20-140 \mathrm{~mm}$.

Widely distributed throughout the Indo-Pacific, from the middle part of Japan to Africa, the Southern Sea and Mexico. 
Kuhlia rupestris (LACÉPÈDE) Ōkuchi-yugoi

Found in association with $D$. taeniurus but not as abundant. One specimen, $105 \mathrm{~mm}$ long, from Nakanoshima.

This species lives in the waters from Okinawa to Africa, Australia and Polynesia. K. marginata (Cuvier \& VALEnciennes) Yugoi Native name: Mukyō (Nakanoshima)

Common. Many specimens, 80-150 $\mathrm{mm}$ long, were collected in enclosed blackish pools and brooks at Miyazuru in Nakanoshima. Dr. TANAKA states that this species is a synonym of rupestris.

Widely distributed throughout the Indo-Pacific, from the middle part of Japan to Africa, Micronesia, Melanesia and Polynesia.

\section{Serranidae}

The natives are quite confused over names for most of the species of this family and although they know a great number of names for sea basses, they are often uncertain about using them correctly.

Variola louti (ForSKÅL) Bara-hata Native name: Aka-nebaru (Takarajima)

Several specimens, about $300 \mathrm{~mm}$ long, seen in Takarajima, but were dispatched by the natives before they could be preserved. It bites on a hook at night, and is prized for food by the natives.

Widely distributed in the Indo-Pacific, the species has been known from Prov. Tosa, which is probably its northern limit in range.

Cephalopholis argus BLoch \& SchNeIDER Goma-hata (new Japanese name) Native name: Garasu-chota (Takarajima); Kuro-sebi (Nakanoshima)

Color dark purplish brown; head, body and fins covered with blue small spots ringed with black. Soft dorsal, anal and caudal narrowly margined with whitish.

Solitary individuals live in tide pools. Four specimens, $86-150 \mathrm{~mm}$ long, from both islands.

The species was recorded from the regions from China to Africa, New Guinea, Samoa and Hawaii. It was never known from Riu Kiu and Formosa.

Epinephelus summana caeruleopunctatus (BLOCH) Hakuten-hata Native name: Garasunebaru (Takarajima)

Color dark purplish brown, with round whitish spots which extend onto vertical fins. Maxillary groove edged with black.

Three specimens, $90-250 \mathrm{~mm}$ in length, from Takarajima.

The species is known in the regions from Riu Kiu to Africa, Australia, Melanesia and Micronesia. Mr. S. MASUdA reports this form from Hamamatsu, Misaki and Okitsu, Chiba Prefecture which is probably its northern limit in range (Annot. Zool. Japon., vol. 21 , no. $2 ; 1942$ ). 
W. merra merra BLoch Kanmon-hata Native name: Watanaga or Chota (Takarajima); Nebaru or Ara (Nakanoshima)

Common in both islands. Many specimens, $60-240 \mathrm{~mm}$ long, from both islands.

Widely distributed in the Indo-Pacific region, from Red Sea to Madagascar, Australia, Polynesia and Hawaii. It was recorded from Okinawa.

E. merra megachir (RICHARDSON) Moyō-hata Native names of this species are the same as those of Kanmon-hata.

Common in both islands. Many specimens, $60-190 \mathrm{~mm}$ long, from both islands. The species is distributed in the regions from Southern Japan to India and Australia.

E. moara moara (TEMminck \& SChLEgel) (Fig. 7) Kue

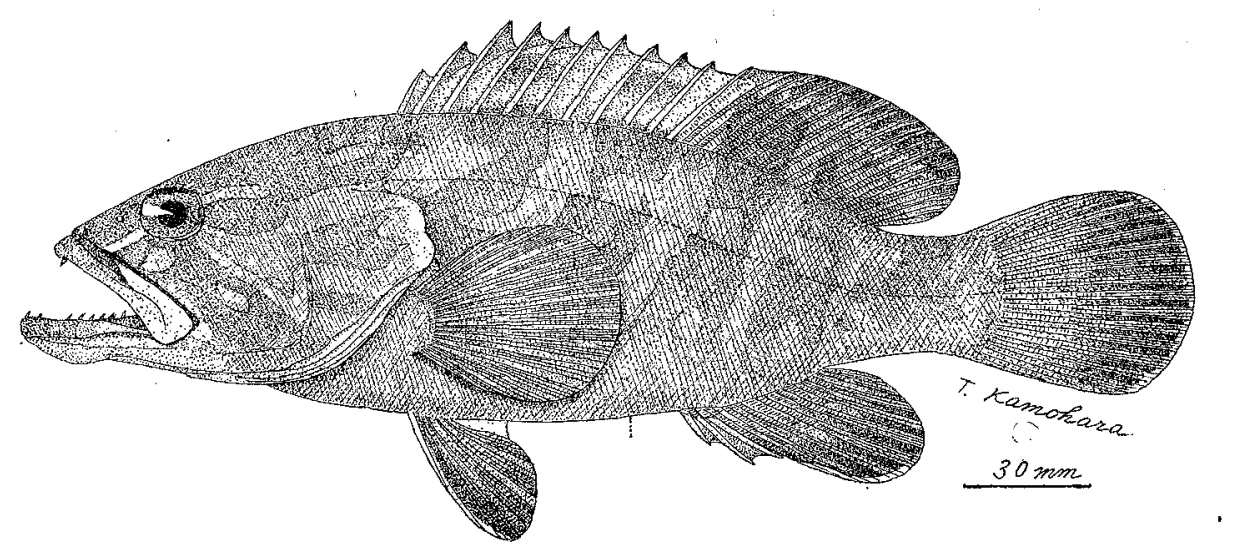

Fig. 7. Epinephelus moara moara (TEMMINCK \& SCHLEGEL).

A young, $32 \mathrm{~mm}$ long, from Takarajima.

The species lives in the waters from the middle part of Japan to Fuzan and Hong-Kong.

Pseudanthias taira ScHMIdT Riū-Kiū-hanadai

A young, $26 \mathrm{~mm}$ long, from Nakanoshima.

Hitherto known only from Amami-Ōshima.

Grammistes sexlineatus (THUnBerG) Nunozarashi Native name: Egu-yuo (Takarajima)

Dorsal fins separate. Color dark brown generally, with several broad longitudinal yellowish bands.

Solitary individuals live in tide pools. Rather common. Several specimens, 60$90 \mathrm{~mm}$ long, from both islands.

Widely distributed in the tropical waters from Africa to Polynesia, the species extends as far north as Prov. Kii, Japan. 


\section{Pharopterycidae}

\section{Plesiops oxycephalus BLEEKER Nakahara-tanabata-uo}

Several specimens, 60-70 $\mathrm{mm}$ long, from Takarajima.

Distributed in the regions from. Southern Japan to the East Indies.

\section{Lutianidae}

Pristipomoides sieboldi (BleEker) (Fig. 8) Chibiki Native name: Aka-matsu (Takarajima); Matsudai (Nakanoshima)

Common. Fished with hook and line, but not collected. It is one of the main food fishes of the natives.

The species lives in the waters from the middle part of Japan to Riu Kiu and Hawaii.

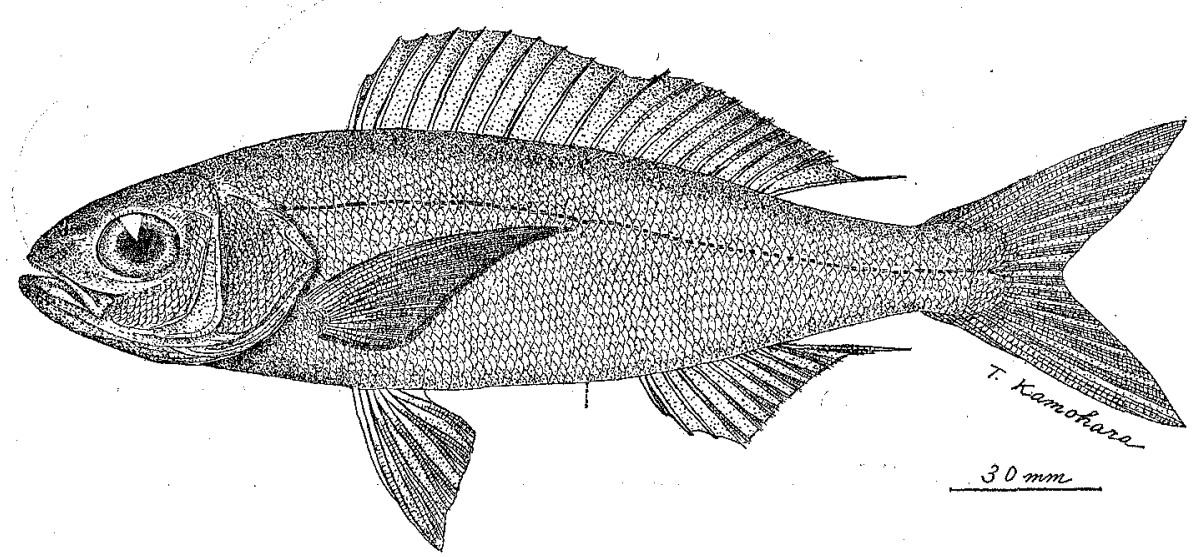

Fig. 8. Pristipomoides sieboldi (BLEEKER).

Etelis carbunculus Cuvier \& VALENCIENNEs Hamadai Native name: Onaga (Takarajima)

Rather common. The natives catch it with hook and line and value it for food; not collected.

This species is widely distributed in the tropical seas, from Madagascar to Australia and Hawaii, and also in the Atlantic Ocean. It ranges as far north as the middle part of Japan.

Lutianus fulviflamma (FORSKÅL) Montsuki Native name: Shūbi (both islands)

Characterized by a large diffuse blackish blotch on lateral line below soft dorsal origin.

Rather common in both islands. Young of this species occur in smail schools in tide pools. Several specimens, $100-200 \mathrm{~mm}$ long, from both islands. 
It is known in wide regions from Southern Japan and Fuzan to Africa, Australia and Polynesia.

L. vaigiensis (QUOY \& GAIMARD) Dokugyo

One specimen, $162 \mathrm{~mm}$ long, from Takarajima.

Widely distributed in the seas from Southern Japan to Africa, Australia and Polynesia.

\section{$\stackrel{\ell}{\text { Haemutidae }}$}

Paracaesio caeruleus (KaTAYAMA) Aodai Native name: Ao-matsu (Takarajima)

Rather common. Fished with hook and line; not collected. It provides an important food for the natives.

The species was recorded from the regions from Prov. Kii to Kagoshima and Hachijojima.

Plectorhynchus diagrammus (LINNÉ) Suji-korodai (new Japanese name) Native name: Kokore (Nakanoshima)

Color yellowish gray generally, with 6 longitudinal dark brown bands.

One specimen, $165 \mathrm{~mm}$ in length, from Nakanoshima.

This species is known in the regions from Philippines to Africa, Melanesia, Micronesia and Polynesia. It has not hitherto been recorded from Riu Kiu and Formosa.

Scolonsis bilineatus (BLOCH) Futasuji-tamagashira

Color brownish olive, golden below. Two margaritaceous stripes, running from above eye and from hindborder of eye, parallel to each other, to base of soft dorsal. A third much broader band from snout below eye to end of dorsal.

Small schools observed in tide pools. Four specimens, $105-117 \mathrm{~mm}$ long, from Nakanoshima.

The species lives in the seas from Riu Kiu to India (Andaman Islands) and Melanesia.

\section{Sparidae}

Pagrosomus major (Temmincr \& Schlegel) Madai

According to the natives this species is rather common near Takarajima. Fished with hook and line; not collected.

The species is distributed in the regions from Hokkaido to Southern China and Hawaii.

\section{Kyphosidae}

Girella mezina JoRdan \& STARISS Okina-mezina Native name: Kuro-io (young), Subatsu (adult) (Takarajima); Shitsuo (Nakanoshima) 
Readily known from related species by having a conspicuous crossbar of yellowish white on the middle of body. Small schools or scattered individuals present in tide pools.

Common in both islands. Numerous specimens, $30-200 \mathrm{~mm}$ long, from both islands.

The species is known in the regions from Chiba Prefecture to Canton.

G. punctatus GraY Mezina Native name: Kure-yuo (Nakanoshima)

Rather common in tide pools in both islands. Three specimens, $50-150 \mathrm{~mm}$ long, from Nakanoshima.

It is known in the regions from Hokkaido and Fuzan to Philippines and Canton.

\section{Mullidae}

Pseudupeneus fraterculus (Cuvizr \& Valenciennes) Hōrai-uo Native name: Katayasu (Nakanoshima)

Several young, $40-55 \mathrm{~mm}$ long, from the rock pools in both islands.

The species is known in the regions from Tokyo to Africa.

\section{Aplodactylidae}

Goniistius zonatus (Cuvier \& Varenciennes) (Fig. 9) Talanoha

One specimen, $140 \mathrm{~mm}$ long, from Nakanoshima.

The species lives in the seas from the middle part of Japan and Fuzan to Southern China.

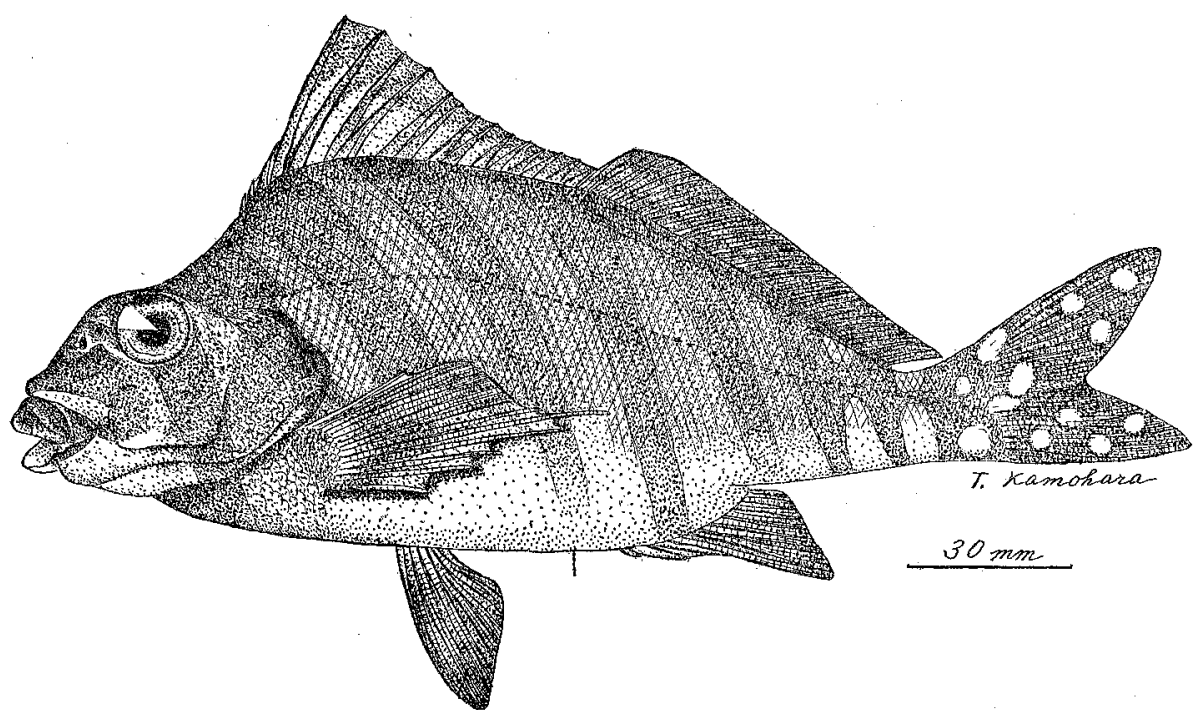

Fig. 9. Goniistius zonatus (CUVIER \& VALENCIENNES). 


\section{Cirrhitidae}

Cirrhites pinnulatus (BLOCH \& SCHNETDER) Shirohoshi-gombe Native name: Gabu (Takarajima)

D. X. 11 ; A. III, 6 ; L. 1. 38-40. Head 2.5 in length without caudal; depth 2.72.8 ; eye 4.5 in head. Preopercle margin finely serrate. Scales on cheeks minute, in about 20 transverse rows; interopercle with small scales. Eyes subequal to interorbital space, which is concave. Maxillary reaching to below middle of eye; nostrils close together, the anterior one with a posterior flap, which is fringed at the top. Color violet-gray; head and body with numerous reddish brown spots; large white blotches on side, more or less regularly arranged in rows.

Three specimens, 145-156 mm long, from Takarajima.

This Indo-Pacific species has been known from Prov. Kii, Japan northwards.

\section{Pseudochromidae}

\section{Pseudochromis cyanotaenia BLEEKER Riū-Kin̄-nise-suzume}

Color purplish blue; the lower half of head, breast and paired fins lemon yellow in sharp contrast with the blue on the rest of body.

Four specimens, $45-48 \mathrm{~mm}$ long, from Nakanoshima.

This species is known from the regions from Riu Kiu to the East Indies and Australia.

P. xanthochir BLEEKER Kibire-nise-suzume

Color buff brown generally. Dorsal and caudal yellowish; pectoral, ventral and anal pinkish.

Three specimens, $43-57 \mathrm{~mm}$ long, from Nakanoshima. It is known in the regions from Riu Kiu to India.

\section{Pomacentridae}

The natives have names for some of the species of this family but most of the pomacentrids have no names. Kunobera, Munadaka and Heki are general names referred to some species in Takarajima, but the natives are not sure for just how many damsel fishes these terms are correct.

Abrudefduf notatus (DAY) Iso-suzumedai Native name: Kunobera (Takarajima); Hitsuo (Nakanoshima)

Characterized by 5 pale vertical bands on body.

Common in both islands. Several specimens, $80-130 \mathrm{~mm}$ long, were secured.

The species lives in the seas from the middle part of Japan to India.

A. septemfasciatus (CUVIER \& VALENCIENNES) Shichisen-suzumedai Native name: Munadaka (Takarajima); Unadaka (Nakanoshima) 
Color lemon yellow, with 7 blackish crossbands which are wider than interspaces between them. Spinous dorsal margined with brownish; base of caudal with a black spot superiorly.

Common in both islands. Many specimens were secured. Length 70-150 mm.

Widely distributed in the regions from Okinawa to Africa, Melanesia, Micronesia and Polynesia.

\section{A. uniocellatus (QUOY \& GAIMARD) Ichimon-suzumedai}

Color chocolate brown generally. Dorsal with one black blotch at the base of posterior rays.

Common in both islands. Numerous specimens, $70-80 \mathrm{~mm}$ long, were secured.

Widely distributed in the seas from Riu Kiu to India, Australia, Micronesia and Polynesia.

A. albifasciatus (HAMBRON \& JACQUINOT) Miyako-suzumedai

Color olivaceous generally, with 3 yellowish vertical bands; cheek with a yellowish spot.

Common in both islands. Many specimens were secured. Length $50-70 \mathrm{~mm}$.

Distributed in the warm seas from Riu Kiu to India.

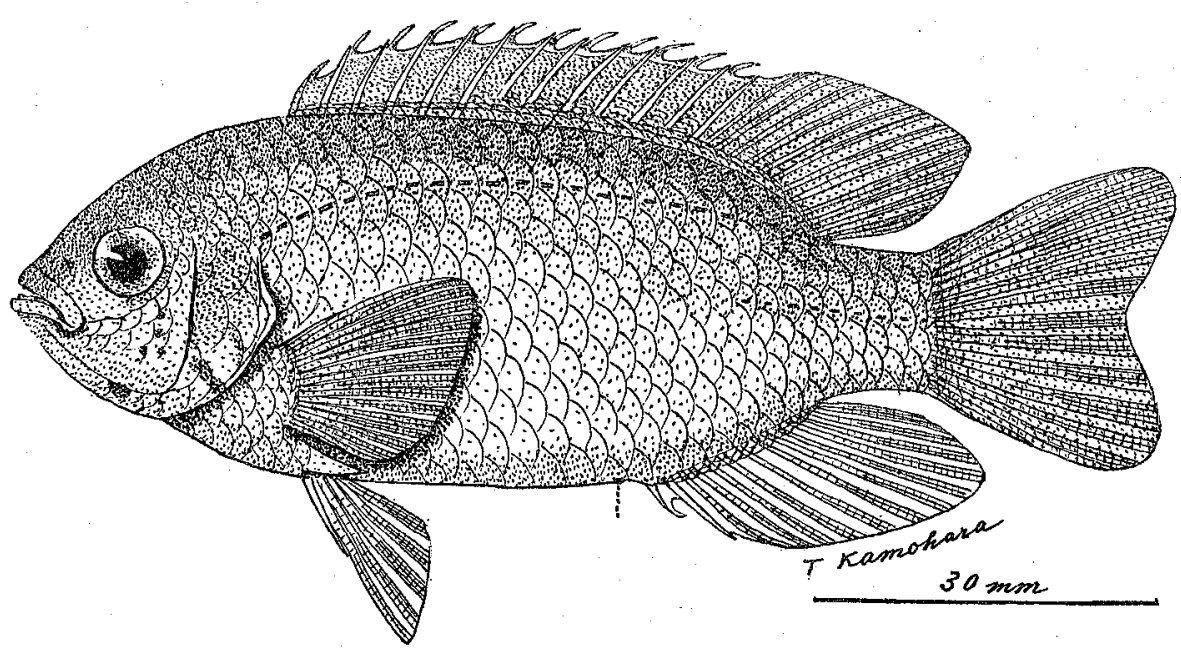

Fig. 10. Abudefduf glaucus (CUVIER \& VALENCIENNES).

A. glaucus (Cuvier \& Valenciennes) (Fig. 10) Nezu-suzumedai Native name: Mehage (Takarajima)

Color yellowish gray generally; spinous dorsal with a submarginal longitudinal pale streak; vent blackish.

Common in both islands. Small schools present in tide pools. Many specimens, 80-100 mm long, were secured. 
Occurs in the seas from Misaki, Kanagawa Prefecture to India, Melanesia, Micronesia and Polynesia. Recently I have collected the fish at Okinoshima Island, Prov. Tosa.

A. yamashinai OKADA \& IKEDA Yamashina-suzumedai Native name: Kunobera (Takarajima)

Color chocolate brown generally, paler below; a white band covering three series of scales passing across the body from base of sixth, seventh and eighth dorsal spines to front of vent; upper edge of pectoral with a black spot.

Rather common. Many specimens. 70-110 mm long, from Takarajima.

Hitherto known only from Miyakojima, near Formosa.

\section{A. leucozonus (BLEEKER) Hakusen-suzumedai}

Color yellowish brown, with a white vertical band descending from sixth, seventh and eighth dorsal spines; a large black ocellus edged with white at base of last three dorsal spines, above the lateral line; another black spot on back of tail immediately after dorsal fin; a small one superiorly at base of pectoral.

Two specimens, 25 and $52 \mathrm{~mm}$ long respectively, from Takarajima.

The species lives in the seas from Chiba Prefecture to the East Indies and Polynesia.

A. cyaneus (QUOY \& GAIMARD) Tsumaguro-ruri-suzumedai

Color deep gray-blue generally; each scale with narrow. light blue basal spot; vertical fins margined with dusky brown.

One specimen, $61 \mathrm{~mm}$ long, from Takarajima.

The species is widely distributed in the seas from Riu Kiu to the East Indies and the Southern Sea.

A. biocellatus (QUOY \& GAIMARD) Kinran-suzumedai

Color brown, paler below. A band of azure blue extends from upper edge of eye to the black ocellus on last dorsal spines; another small black ocellus at base of last dorsal rays.

Two specimens, 16 and $45 \mathrm{~mm}$ long respectively, from Takarajima; another two, 17 and $29 \mathrm{~mm}$ long respectively, from Nakanoshima.

Known in the regions from Tanegashima to Red Sea and Africa.

A. richardsoni SNYDER Okinawa-suzumedai

Scales in longitudinal series 27; 3 above lateral line, 9 below. Color yellowish brown, paler below. Each lobe of caudal with a broad blackish longitudinal band marginally, the upper extending to the base of last dorsal ray, the lower running along caudal peduncle. Spinous dorsal blackish; soft dorsal and anal margined with blackish.

One specimen, $39 \mathrm{~mm}$ long, from Takarajima. 
Hitherto known only from Okinawa.

A. sexfasciatus LACÉPÉDE Rokusen-suzumedai Native name: Heki (Nakanoshima)

Color grayish, with 5 blackish vertical bands, not quite to lower body edge.

One specimen, $80 \mathrm{~mm}$ long, from Nakanoshima.

Widely distributed in the seas from Suruga Bay to Africa, Australia and Polynesia.

A. sordidus (FORSKÅL) Shima-suzumedai Native name: Munadaka (Takarajima)

Color olivaceous brown, whitish below. Seven paler vertical streaks, whitish in young, not more than 1 or 2 scales wide and much narrower than darker intervening bands. A black spot present at pectoral base; another larger black spot present on upper front of caudal peduncle.

Common in Takarajima. Many specimens were collected there. Length 100$200 \mathrm{~mm}$.

Widely distributed in the waters from the middle part of Japan to Red Sea, Australia, Polynesia and Hawaii.

A. saxatilis (LINNÉ) Oyabitcha Native name: Ayabiki (Takarajima); Madara-heki (Nakanoshima)

Color dark gray, lighter below. Side of body with 6 broad blackish vertical bands becoming indistinct below.

Common in both islands. Many specimens were secured. Length $50-130 \mathrm{~mm}$.

Widely distributed in the regions from the middle part of Japan to Africa, Australia and Polynesia. It is also known from the West Indies.

Pomacentrus coelestis JoRdan \& Starks Sora-suzumedai

A very rare and handsome species. Solitary individual very rarely seen in Nakanoshima; not collected.

Recorded from the regions from the middle part of Japan to Riu Kiu.

\section{Labridae}

The largest fish family and certainly one of the most conspicuous groups at Takarajima is the Labridae. The natives have names for some of the species. Nobosu is a general name referred to some species, but they are not sure for just how many fishes this term is correct.

Anampses caeruleo-puneta tus RüPPELL (Fig. 11) Buchi-susuki-bera Native name: Nobosu (Takarajima)

Three specimens, 108-140 mm long, from Takarajima; another one, $45 \mathrm{~mm}$ long, from Nakanoshima.

Widely distributed throughout the Indo-Pacific, from Africa to Polynesia. In Japan it extends as far north as Prov. Kii. 


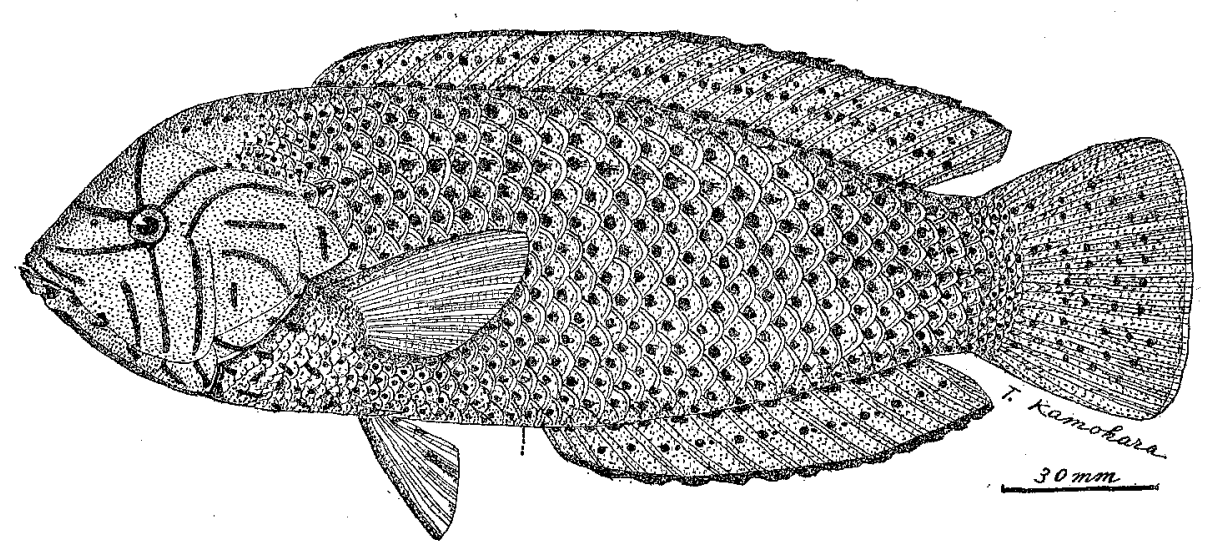

Fig. 11. Anampses caeruleo-punctatus RüPPELL.

A. twistii BLEEKER Hoshi-susuki-bera (new Japanese name)

L. 1. 29. Caudal rounded. Color reddish green; fins yellowish; soft dorsal and anal with a small round black ocellus posteriorly, much smaller than eye; a light brown patch as large as pupil at base of middle caudal rays.

One young, $34 \mathrm{~mm}$ long, from Nakanoshima, and five, $25-39 \mathrm{~mm}$ long, from Takarajima, are referred with considerable doubt to this species.

The species has been known in the regions from the East Indies and Mauritius. For once from Japan.

Stethojulis axillaris (QUOY \& GAIMARD) Kurohoshi-bera Native name: Ama-yuo (Takarajima)

Color yellowish brown. One to three small black ocelli at the middle part of caudal base.

Several specimens, $60-105 \mathrm{~mm}$ in length, from both islands.

The species is widely distributed in the regions from Riu Kiu to Red Sea, Africa, Australia, Samoa and Hawaii.

S. trilineata (BLOCH \& SCHNEIDER) Oni-bera (new Japanese name)

Color bluish brown, with 3 longitudinal reddish bands, the second from tip of snout to axil of pectoral.

Two specimens, 135 and $140 \mathrm{~mm}$ long respectively, from Takarajima.

It has been known in the regions from Philippines to Red Sea. For once from Japan.

S. phekadopleura (BLEEKER) Niji-bera

Color reddish brown, paler below. Red streak along body at level of pectoral base; pale longitudinal series of spots on lower half of body; dorsals finely dotted with grayish.

Five specimens, $80-125 \mathrm{~mm}$ long, from Takarajima. 
Distributed in the regions from the middle part of Japan to the East Indies, Australia and Polynesia.

\section{S. kalosoma (BLEEKER) Kaminari-bera}

Color brown above, finely vermiculated, spotted or varied with darker. Lower half of body pale, with longitudinal rows of small white spots. Dorsal with oblique blue streaks.

A single specimen, $63 \mathrm{~mm}$ long, from Takarajima.

The species is distributed in the regions from the middle part of Japan and Fuzan to Africa, Red Sea, Australia and Polynessia.

Halichoeres centriquadrus (LACÉPÈDE) Tokara-bera (new Japanese name)

Opercle above and postocular scaly. Color yellowish brown, pale below; an yellow spot below front dorsal spines on the back and another at front of soft dorsal. Each scale on back with a dark vertical bar.

Several specimens, 70-190 $\mathrm{mm}$ long, from Takarajima.

Recorded from the regions from Formosa to Africa and Samoa.

H. margaritaceus (Cuvier \& VALENCIENNES) Aka-niji-bera Native name: Yasena (Takarajima)

Color bluish brown, pale below, with several dark brown blotches on back and sides. A large reddish blotch at the middle part of the side of body. A dark spot, less than pupil, behind eye. Dorsals pale, with brown waved vertical bands; a small black ocellus at front of spinous dorsal and a larger one at front of soft dorsal.

Rather common in both islands. Several specimens, 70-100 mm long, were collected.

Distributed in the seas from Okinawa to Africa, Australia and Samoa.

H. mebulosus (VALENCIENNES) Inazuma-bera (new Japanese name)

Color bluish brown, with several ill-defined dark brown blotches on the side of body. Dorsal with a marginal and a basal row of yellow spots. A dark spot behind eye, larger one on opercle. Black spot, as large as eye, at front of soft dorsal.

Rather common in both islands. Many specimens, $105-140 \mathrm{~mm}$ long, were collected. Widely distributed in the seas from Riu Kiu to Red Sea, Australia and Samoa.

H. trimaculatus (QUOY \& GAIMARD) Mitsuboshi-kyūsen

Color yellowish gray; each scale with subterminal dark vertical streak. Dusky blotch at fifth or sixth scale of lateral line and another one at upper side of caudal peduncle above lateral line.

Rather common in both islands. Many specimens, 77-143 mm long, were collected. Known in the regions from Riu Kiu to the East Indies, Micronesia and Samoa. H. prosopeion (BLEEKER) Munaten-bera

Characterized by a large black basal pectoral spot and by dorsals and anals with longitudinal blue lines. 
One specimen, $100 \mathrm{~mm}$ long, from Takarajima agrees entirely with specimens from the East Indies and New Guinea. The species extends as far north as Prov. Kii. H. notopsis (CUVIER \& VALENCIENNES) Hakusen-bera Native name: Kuro-nobosu (Takarajima)

Color blackish brown generally. About 6 white longitudinal lines inconspicuous in large specimens. Black ocellus, larger than eye, at front of soft dorsal; caudal white.

Common in both islands. Many specimens, $50-120 \mathrm{~mm}$ long, were collected. Three small specimens, about $10 \mathrm{~mm}$ long, from Nakanoshima seem to be referable to this species.

The species lives in the seas from Okinawa to India, Australia and Samoa.

H. binotopsis (BLEEKER) Ami-bera (new Japanese name)

Color bluish gray, reticulated with dark brownish; a black red-edged spot at caudal base above. Dorsal with two black red-edged spots, the first between first and second spines and the second between first and third rays.

One specimen, $67 \mathrm{~mm}$ long, from Nakanoshima.

Distributed in the seas from Philippines to the East Indies. First Japanese record.

H. scapularis (BENNETT) Seiten-bera (new Japanese name)

H. cymatogrammus JORDAN \& SEALE

D. IX, 13; A. III, 11; L. 1. 28. Caudal slightly rounded. Color yellowish green; a distinct dark brown band, slightly wider than pupil, from posterior margin of eye to base of caudal; a bluish brown patch between eye and upper lip; fins yellowish without markings.

Two specimens, 45 and $75 \mathrm{~mm}$ in length respectively, from Takarajima.

Hitherto known only from Philippines. This is one of an unexpected addition to the Japanese fish-fauna.

Coris imbris TANAKa Shike-bera Native name: Hanbun-nobosu (Takarajima)

This species is well figured and exactly described by Dr. Tanaka (Fig. Descr. Fish. Jap., vol. 29, 1918, pl. CXXXVIII, fig. 386).

Rather common in both islands. Several specimens, $130-170 \mathrm{~mm}$ long, were collected.

Hitherto known only from Tosa and Kii ; the locality of my specimens suggests that this species extends in distribution as far south as Riu Kiu.

Pseudojulis trifasciatus M. WEBER Misuji-bera (new Japanese name)

D. VIII, 13; A. III, 11 ; L. 1. 27. Caudal truncate. Color light reddish. A dark band from tip of snout to upper part of caudal base; a second median dark band from between eyes along dorsal base including inferior part of the fin. A black ocellus superiorly at base of pectoral. 
Two specimens, 51 and $60 \mathrm{~mm}$ long respectively, from Takarajima.

This East Indian species is an unexpected addition to the Japanese fish-fauna.

Thalassoma lutescens (SOLANDER) Yamabuki-bera Native name: Nobosu (Takarajima)

Characterized by head with 5 longitudinal brown bands and by pectoral with a broad black terminal blotch.

Three specimens, 130-200 $\mathrm{mm}$ long, from Takarajima.

Widely ranged in the Indo-Pacific, from the East Indies to Australia, Polynesia and Hawaii; the species has been known from Suruga Bay northwards.

T. umbrostigma (RüPPELL) Kinu-bera Native name: Shūbingenta or Aomata-kusabi (Takarajima); Kusabi (Nakanoshima)

Black spots on head; short vertical black lines on scales; green longitudinal band on the middle of soft dorsal and soft anal fins.

Common wherever there is coral growth at both islands. They are secured with hook and line by the natives, occasionally the adults are speared. Many specimens, 30-190 mm long, were collected.

Widely ranged in the seas from Okinawa to Red Sea, Africa, Australia, Polynesia and Hawaii.

\section{T. cupido (TEMminck \& Schlegen) Nishiki-bera}

Native names of this species are the same as those of the above-mentioned species.

Rather common in both islands. Several specimens, $50-120 \mathrm{~mm}$ long, were collected. Dr. TANAKA states that this species is a synonym of $T$. umbrostigma, but this is at once distinguished from the latter by the large black blotch of caudal fin.

The species is known in the regions from the middle part of Japan to the East Indies. T. hardwicke (BENNETT) Senasuji-bera

Characterized by 6 vertical black bands on body. Two specimens, 61 and $64 \mathrm{~mm}$ long respectively, from Takarajima.

The species lives in the tropical seas, from Africa to Polynesia, extends as far north as Prov. Tosa, which is probably its north limit in distribution.

T. jansenii (BLEEKER) Yansen-nishiki-bera

D. VIII, 13; A. II, 11 ; L. 1. 26. Color gray, paler below, with 3 saddle-like brown blotches; the first on head above and predorsal; the second across spinous dorsal; the third and last from soft dorsal to posterior part of anal; caudal peduncle light.

One specimen, $93 \mathrm{~mm}$ long, from Takarajima.

Widely distributed in the seas from Okinawa to Africa, Australia and Polynesia.

Scarichthyidae

Leptoscarus japonicus (Cuvier \& VALENCIEnNes) Budai Native name: Akahachi (Takarajima); Akabachi (Nakanoshima) 
Rather common in both islands. Several individuals, about $500 \mathrm{~mm}$ long, seen; not collected.

This species lives in the seas from the middle part of Japan and Fuzan to the East Indies and Hawaii.

Callyodon ovifrons (Temminck \& Schlegel) Ao-budai Native name: Aohachi

(Takarajima); Aobachi (Nakanoshima)

Rather common in both islands. Several individuals, about $500 \mathrm{~mm}$ long, seen; not collected.

Hitherto known only from Southern Japan.

\section{Chaetodontidae}

\section{Chaetodon collaris BLOCH Chōchō-uo}

The natives say this species is rather common at Takarajima, although only a few individuals were observed during our investigation; not collected.

The species is known in the regions from the middle part of Japan and Fuzan to Red Sea, Madagascar and Micronesia.

C. lunula (LACÉPÈDE) Tsuki-chōchō-uo Native name: Kashira-butsu (Takarajima)

Color brownish generally. A black blotch includes eye, interorbital and cheek,

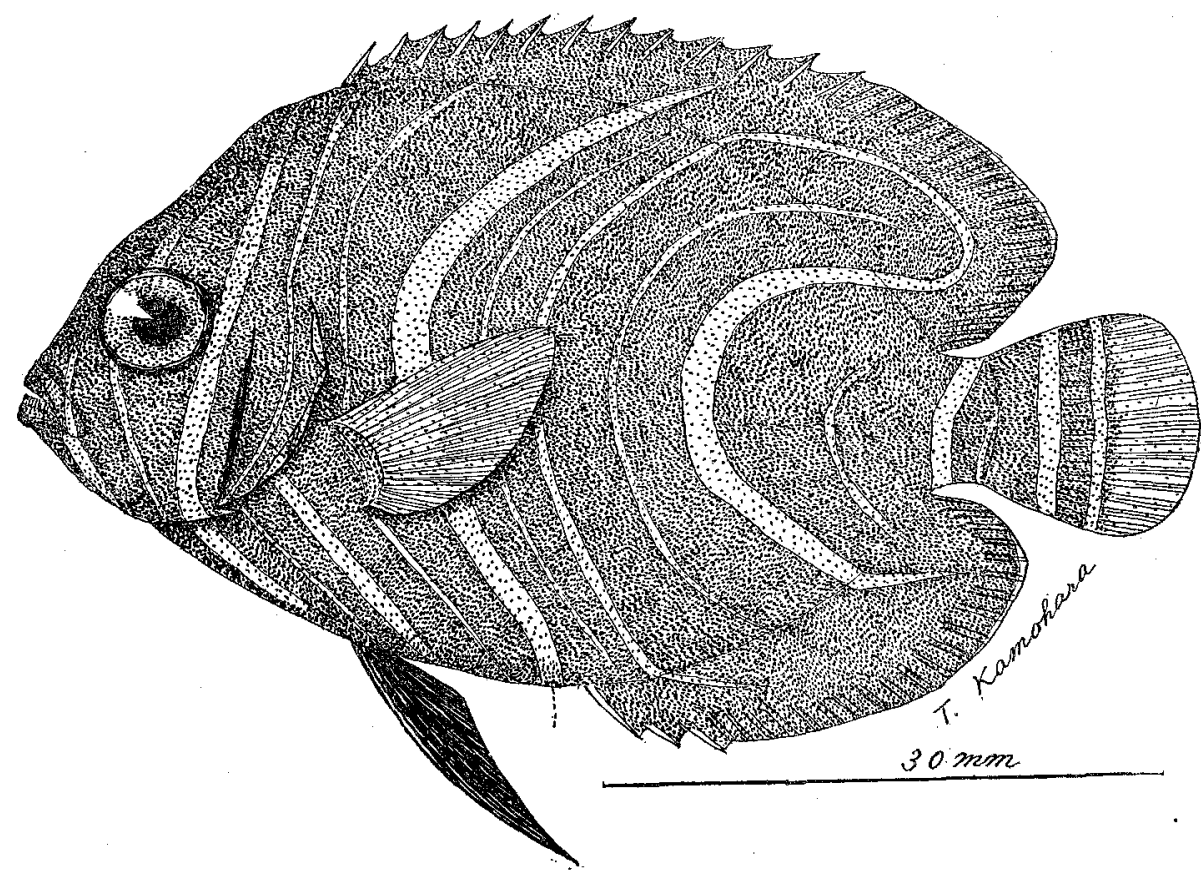

Fig. 12. Holacanthus semicirculatus CUVIER \& VALENCIENNES. 
edged with white; a black band from suprascapula to spinous dorsal base, edged widely whitish.

Three specimens, about $110 \mathrm{~mm}$ long, from Takarajima.

The species is distributed in the seas from Misaki, Kanagawa Prefecture to Red Sea.

Holacanthus semicirculatus Cuvier \&. VAlEnCIEnNes (Fig. 12) Sazanami-yakko

Two young, about $60 \mathrm{~mm}$ long, from Takarajima.

Widely distributed in the seas from Prov. Izu to Africa, Australia and Polynesia. Microcanthus strigatus (CuviER \& VALENCIENNEs) Kagokaki-dai

Characterized by 5 broad longitudinal black bands.

A single young, $45 \mathrm{~mm}$ long, from Takarajima. Distributed in the waters from the middle part of Japan and Fuzan to Australia and Hawaii.

\section{Hepatidae}

Hepatus triostegus (LINNÉ) Shima-hagi Native name: Nenomushi (Takarajima); Yacha (Nakanoshima)

Characterized by 4 vertical brown bands on body.

Common in both islands. Several specimens, $100-150 \mathrm{~mm}$ long, were collected. The species is widely distributed in the regions from the middle part of Japan to Madagascar, Australia, Polynesia and Hawaii.

H. elongatus (LACÉPÈDE) (Fig. 13) Naga-niza Native name: Kōsoku (Takarajima) Color solid brown generally. Two black spots at dorsal and anal bases. Two specimens, 100 and $180 \mathrm{~mm}$ long respectively, from Takarajima.

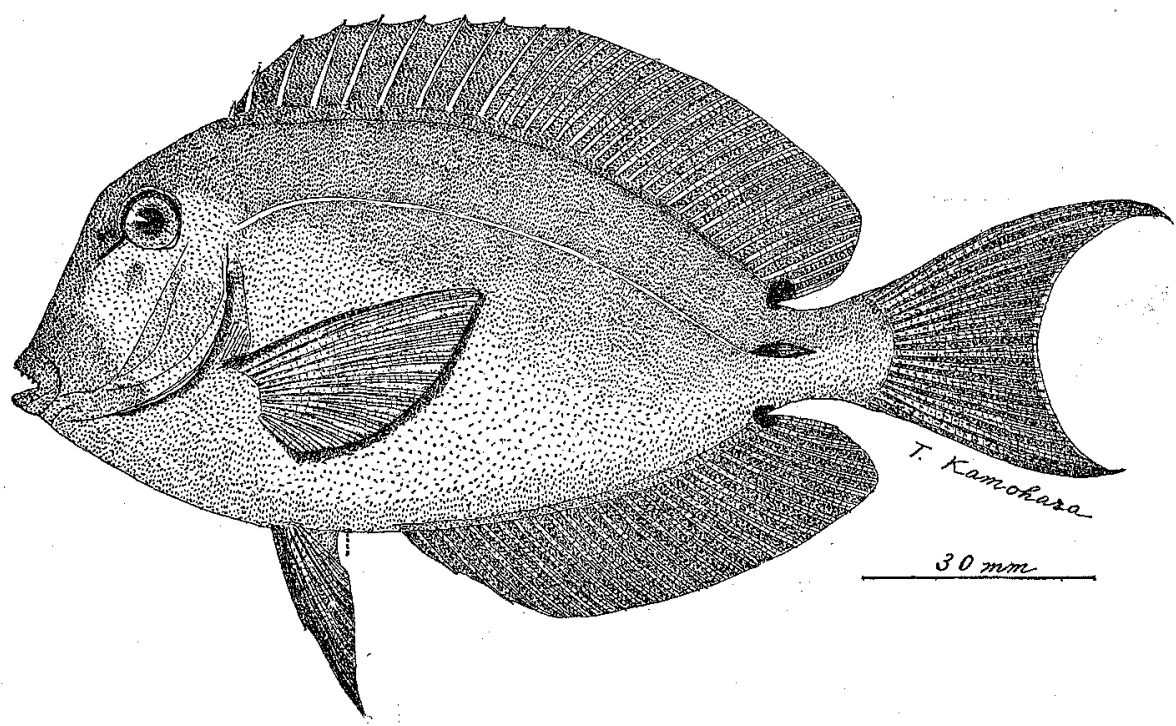

Fig. 13. Hepatus elongatus (LACÉPĖDE). 
It was recorded from the regions from Prov. Kii to the East Indies, Melanesia, Polynesia and Hawaii.

\section{H. fuliginosus (LESSON) Kuro-hagi}

Two specimens, about $100 \mathrm{~mm}$ long, from Takarajima.

The species lives in the seas from Misaki, Kanagawa Prefecture to Africa, Australia, Polynesia and Hawaii.

Naso unicornis (FORSKÅL) Tengu-hagi Native name: Tsunogōme (Nakanoshima)

The natives spear the fish with a single or three-pronged spear called Ozuki; not collected.

The species is known in the regions from the middle part of Japan to Red Sea, Melanesia and Hawaii.

\section{Monacanthidae}

Osbeckia seripta (OSBECK) Sōshi-hagi Native name: Hōke (Nakanoshima)

The natives catch the fish for food with hook and line and occasionally by spear. One seen, but not collected.

The species is a tropical fish of the world.

\section{Diodontidae}

Diodon holacanthus LiNNé Harisenbon Native name: Igafuku (Takarajima); Igabuku (Nakanoshima)

One specimen, about $150 \mathrm{~mm}$ long, from each island.

The species is widely distributed throughout the warm waters of the world.

\section{Scorpaenidae}

Sebastichthys oblongus (GÜNTHER) Takenoko-mebaru

Rather common in both islands. Many specimens, $55-90 \mathrm{~mm}$ long, were collected.

This species has hitherto been found in the regions from Hokkaido to Nagasaki and Korea. The locality of my specimens suggests that it may extend as far south as Riu Kiu.

Scorpaena neglecta neglecta TEMminck \& SCHLEGEL Fusa-kasago

Two specimens, 83 and $91 \mathrm{~mm}$ long respectively, from Takarajima.

The species has been recorded from the regions from Yokohama to Kagoshima and Fuzan. The locality of my specimens suggests that it ranges farther southward to Riu Kiu.

Scorpaenodes guamensis (QUOY \& GAIMARD) Iso-kasago Native name: Angō Takarajima); Aguro (Nakanoshima)

Common in both islands. The natives fear the fish as being venomous. Many specimens, 50-105 mm long, were collected. 
Widely distributed in the seas from the middle part of Japan to Red Sea, Australia, Polynesia and Hawaii.

Synanceja verrucosa (BLOCH \& SCHNEIDER) Oni-daruma-okoze (new Japanese name)

Native name: Angō (Takarajima)

Ventral rays I, 5 ; the fin entirely adnate. No transverse ridge present between eyes; interorbital space deeply concave. A deep depression present below eye and a similar but larger one behind. Mouth vertical; lips finely fimbriated with small dermal cirri. Orbit elevated above general upper profile of head; eye directed upward and outward. Color dark brown with two transverse white bands on side of body; caudal whitish, brown basally, with a broad brown terminal band; pectoral, ventral and anal narrowly edged with white.

One specimen, $150 \mathrm{~mm}$ long, from Takarajima.

Hitherto known in the regions from Okinawa to the East Indies, New Guinea and Samoa.

Pterois radiata Cuvier \& Valenciennes Kimi-okoze Native name: Mino-yuo (Takarajima)

Three young, about $100 \mathrm{~mm}$ in length, from Takarajima.

Widely distributed in the seas from Prov. Kii to Africa, Micronesia, Polynesia and Hawaii.

Amblyapistus taenianotus (CUvIER) (Fig. 14) Tsumajiro-okoze

One specimen, $80 \mathrm{~mm}$ long, from Takarajima. The natives know very little about this species and could not recall no name for it.

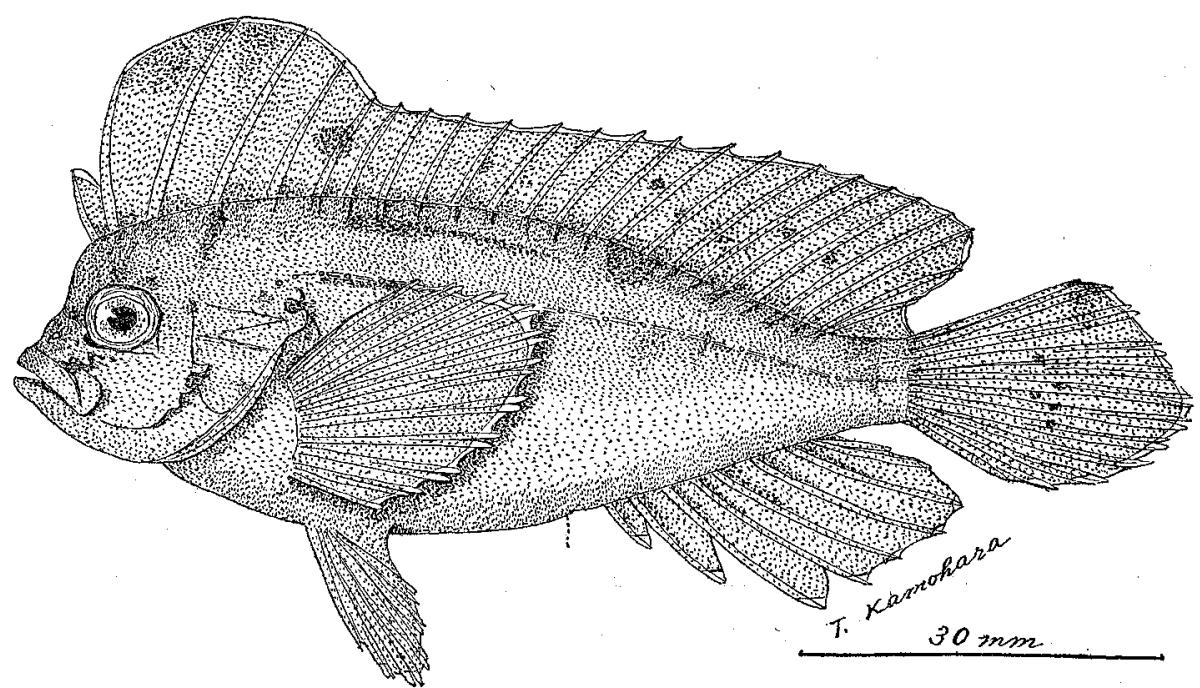

Fig. 14. Amblyapistus taenianotus (CUVIER). 
It has been recorded from the regions from Mauritius, India, the East Indies, Melanesia and Polynesia. I have reported it from Prov. Tosa (Repts. Kochi Univ. Nat. Sci., no. 2, 1952). Recently it has been collected in Prov. Kii by Dr. UTINomr of the Seto Marine Biological Laboratory of Kyoto University.

\section{Platycephalidae}

Thysanophrys serratus (CUVIER \& VALENCIENNES) Hime-gochi (new Japanese name)

D. VIII-12; A. 11; L. 1. ca 60 . Crests on head and suborbital serrated, without spines; lateral line smooth. Color reddish brown, with 6 irregular vertical brown bands. Top of dorsal with a large brown blotch.

One specimen, $114 \mathrm{~mm}$ long, from Takarajima is referred with some doubt to this species.

The species has hitherto been recorded in the seas of the East Indies, Ceylon, Melanesia and New Ireland. The first record from Japan.

\section{Pleuronectidae}

Bothus mancus (BRoussoneT) Mon-daruma-garei (new Japanese name) Native name: Oyanerami or Sunakaburi (Takarajima)

D. 90 (smaller specimen)-99; A. 65 (smaller specimen)-76; P. 9-11; L. 1. ca 90. Body sinistral, ovate; eyes well separated; whole head scaly; caudal pointed. Color pale brownish, everywhere mottled with gray and brown. Head and body with rounded bluish spots edged with darker; a diffuse dark blotch at the junction of straight and curved parts of lateral line, another on middle of straight portion. Right side of body whitish, without any markings.

Three specimens, $120-155 \mathrm{~mm}$ in length, from Takarajima. This fish hides in the sand or in holes during the day and seems to come out to feed at night.

It is known from India, the East Indies, Hawaii and Cocos Island, and was never recorded from Riu Kitu and Formosa.

\section{Soleidae}

Solea heterorhina BLEEKER Sazanami-shita (new Japanese name) Native name: Oyanerami (Takarajima)

D. ca 95 ; A. ca 86 ; V. 4 ; L. 1. ca 120 . Head $5.7-6$ in length without caudal ; depth $2.7-3$; eye $4-4.5$ in head. Body elongate; eyes on right side; caudal free from dorsal and anal; pectorals present on both sides; upper ray of right pectoral slightly longer than snout and upper eye; left pectoral small, its rays rudimentary. Nostrils close together, covered by a cutaneous flap, which is elongated and longer than eye on colored side. Color yellowish, with pairs of dark transverse wavy lines. Dorsal 
and anal have a submarginal black band posteriorly; caudal margined with black, leaving very narrow yellowish edge.

One specimen, $135 \mathrm{~mm}$ long, from Takarajima. In shallow water the fish burrows in sand during the daytime.

The species ranges in the seas from Philippines to India (Andaman Islands), Australia and Samoa. It was never known from Riu Kiu and Formosa.

\section{Eleotridae}

焣viota abax epiphanes JENKINS Midori-haze Native name: Nichobe (Takarajima)

Color greenish yellow; 6 transverse dark patches on body, the last of which is most distinct.

Several specimens, $30-35 \mathrm{~mm}$ long, from both islands.

This species is distributed in the waters from Prov. Tosa to Australia, Polynesia and Hawaii.

\section{Gobiidae}

\section{Callogobius hasselti (BLEEKER) Okinawa-haze}

Many dermal ridges on top and sides of head and on lower jaw. Scales in lateral series about 50. Color brownish, with a faintly outlined dark saddle over back below middle of spinous dorsal.

One specimen, $63 \mathrm{~mm}$ long, from Takarajima.

Distributed in the regions from Riu Kiu to Australia.

Gobius neophytus GüNTHER Sankaku-haze

Color translucent, with spots of dark orange, some of which are jet black, one at caudal peduncle blackest.

Two specimens, $56 \mathrm{~mm}$ in length, from Takarajima.

The species is known in the regions from Riu Kiu to Philippines and Polynesia. G. ornatus ornatus RüPPELL Kazari-haze

Upper pectoral rays free from connecting membrane. Scales in lateral series about 28. Color pale brown, with many longitudinal rows of brown spots and pearl-white spots or dots; on lower half of body two rows of large blackish spots, the lower ones rounded, those of upper row elongated or rectangular.

One specimen, $74 \mathrm{~mm}$ long, from Takarajima; another $51 \mathrm{~mm}$ long, from Nakanoshima.

Widely distributed in the waters from Tanegashima to Red Sea, Australia and Polynesia.

G. fuscus RÜPPELL Kumo-haze 
This species is one of the most abundant in the shallow tide pool area of both islands. Many specimens, 35-95 $\mathrm{mm}$ long, were secured from both islands.

It occurs in almost all tropical and subtropical seas.

G. semidoliatus CuVIER \& VAlEnCIENNEs Irezumi-haze

Color brown anteriorly, olive-yellow behind; anterior parts to vent sharply marked by blunt gray crossbars, each darker edged.

One specimen, $42 \mathrm{~mm}$ long, from Takarajima.

The species is widely distributed in the seas from Tanegashima to Red Sea and Polynesia.

G. eugenius (JoRDAN \& EvERMANN) Benkei-haze

Ventral sucker bilobed posteriorly, without anterior fraenum. Color gray, each scale with a dark edge; head and body with 12 light, vertical bands.

Four specimens, 40-58 mm long, from Takarajima.

The species ranges from Hachijojima and Tanegashima to the East Indies.

Periophthalmus cantonensis (OSBECK) Tobi-haze Native name: Kikunomi (Takarajima)

None were found, deposite repeated research where the fishes were supposed to occur. It is said to occur at Suwanosejima.

The species is known in the regions from the Tōhoki district of Japan and Korea to Africa, Australia and Polynesia.

\section{Pteropsaridae}

Parapercis tetracantha (LACÉPÈDE) Mon-toragisu (new Japanese name) Native name: Bōne or Bōni (Takarajima)

D. IV, 21 ; A. 17 ; L. 1. ca 65 . Color brownish, lighter below; 10 dark brown crossbars on sides and belly, the first through pectoral base, the second below origin of dorsal, the last through caudal peduncle to base of caudal. Caudal light, with several transverse rows of black spots.

One specimen, $80 \mathrm{~mm}$ long, from Takarajima.

The species is distributed in the waters from Riu Kiu to Bengal Bay, Micronesia and Polynesia.

\section{Callionymidae}

\section{Synchiropus ocellatus (Pallas) (Fig. 15) Kōwan-teguri}

In male, all dorsal spines very elongated, with 4 ocelli and 5 oblique irregular blackish bands. In female, dorsal spines not elongated and without ocelli or bands. Anal much paler than in male and with 4 oblique blackish bands. S. ijimae JorDaN \& TrIompson (1914) from Misaki and S. shoe OKadA \& IKEDA (1937) from Okinawa 


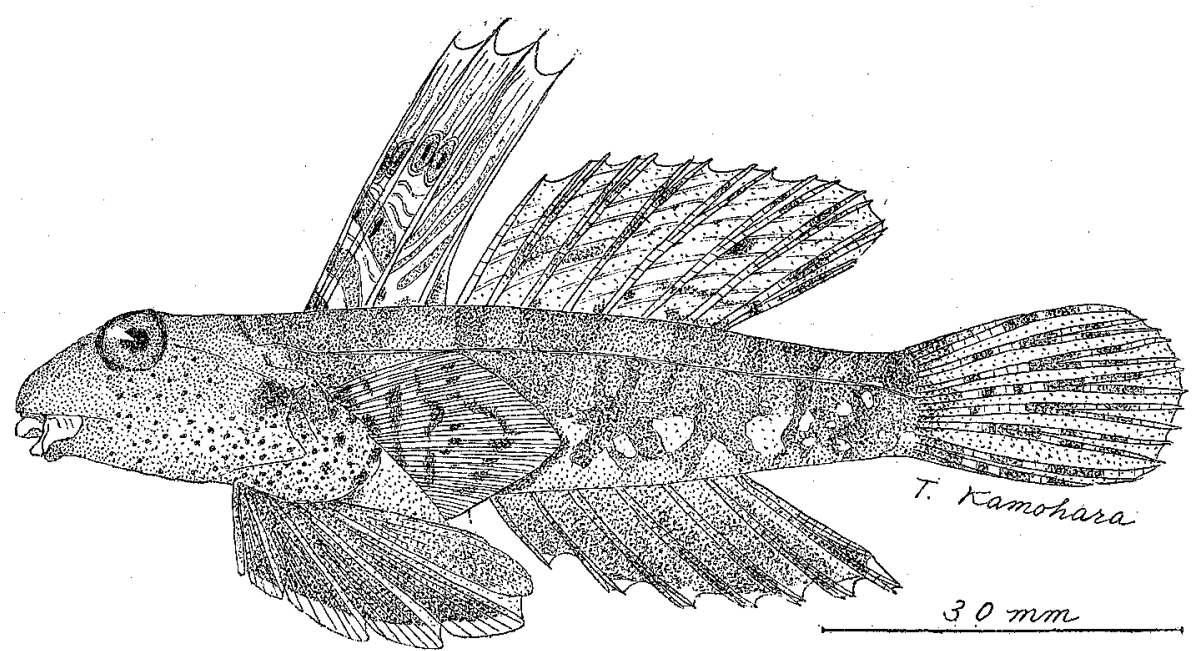

Fig. 15. Synchiropus ocellatus (PALLAS). (male)

seem to be color variants of this species.

Two male, about $100 \mathrm{~mm}$ long, and one female, $75 \mathrm{~mm}$ long, from Takarajima.

Widely distributed in the seas from Misaki, Kanagawa Prefecture to Africa, Australia and Samoa.

\section{Gobiesocidae}

Aspasma misakia TANAKA Misaki-uba-uo

My specimen well agrees with Dr. TANAKA's description and figure in the "Fig. Descr. Fish. Jap., vol. 4, 1911, p. 58".

A single specimen, $20 \mathrm{~mm}$ long, from Nakanoshima.

It is known in the regions from Chiba Prefecture to Okinawa.

\section{Blenniidae}

The fishes of the family form one of the most abundant fishes on the reefs in this district. All blennies are called Nichobe or Nichirobe (Takarajima) and Mitchabe (Nakanoshima) by the natives. They pay no attention to them, none are used for food. Some of these blennies agilely climb over even the vertical rock face and were reluctant to jump back into the water.

Enneapterygius etheostoma (JORDAN \& SNYDER) (Fig. 16) Tsubame

Most abundant fish in tide pools of both islands, especially in Nakanoshima. Numerous specimens, $30-60 \mathrm{~mm}$ long, were secured. The fish seems to undergo considerable changes with growth.

Known in the regions from Chiba Prefecture to Okinawa. 


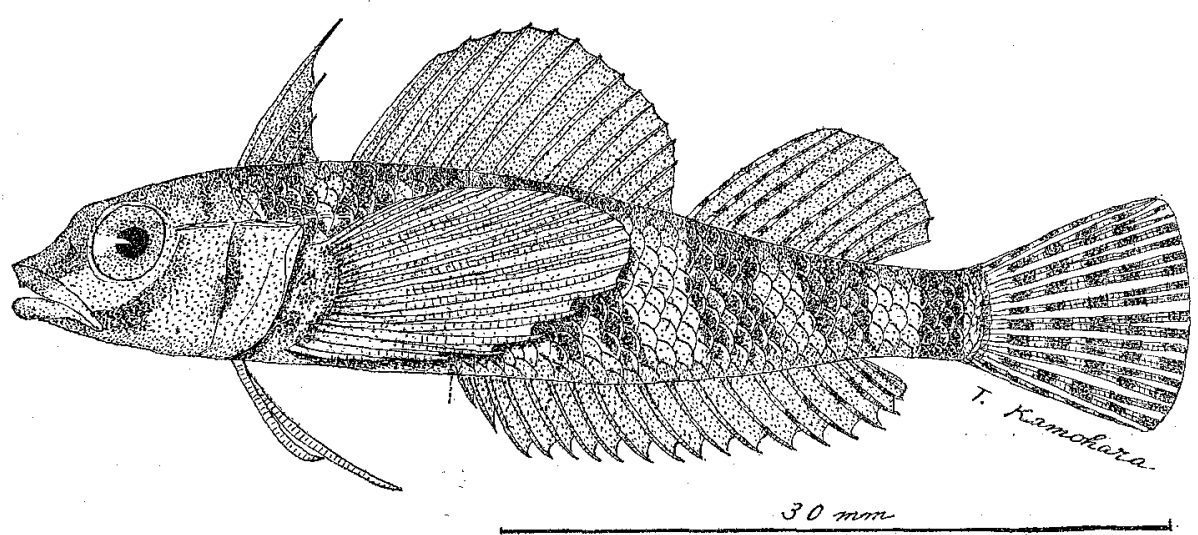

Fig. 16. Enneapterygius etheostoma (JORDAN \& SNYDER). (male)

Tripterygion articeps (JENKINS) Irezumi-gimpo (new Japanese name)

Color yellowish brown, side of body with 6 pairs of dark brown irregularly vertical bars more or less confluent. Head marked with bluish brown.

Four specimens, about $35 \mathrm{~mm}$ long, from Takarajima. The natives have no name for this fish, being too small to be any consequence to them.

Hitherto known only from Hawaii.

Istiblennius enosimae (JoRDAN \& SNYDER) Kaeru-uo

Common in both islands. Many specimens, $60-130 \mathrm{~mm}$ long, were secured.

Occurs in the seas from the middle part of Japan to Riu Kiu.

I. edentulus (BLOCH \& SCHNEIDER) Nise-kaeru-uo (new Japanese name)

Color dull brown, side of body finely dotted brown posteriorly; one oblique brown bar behind eye.

Rather common at Nakanoshima. Length $60-135 \mathrm{~mm}$.

Widely distributed in the seas from China to Red Sea, Madagascar, Australia, Melanesia, Polynesia and Hawaii. The species was never known from Riu Kiu and Formosa.

I. tanegashimae (JORDAN \& STARKS) Tane-gimpo

Rather common in both islands. Many specimens, 40-100 mm long, were collected.

The species ranges from Suruga Bay to Miyakojima, near Formosa.

I. lineatus (Cuvier \& VALENCIENNES) Sen-kaeru-uo

Color dusky generally, side of body with several dark narrow longitudinal lines. Five specimens, 93-140 $\mathrm{mm}$ long, from Nakanoshima.

The species is known in the regions from Okinawa to Red Sea, Australia, Melanesia, Micronesia, Polynesia and Hawaii. Recently Dr. TomiYama has recorded it from Tanegashima (Annot. Zool. Jap., vol. 25, 1952, p. 302). 
I. cyanostigma BLEEKER Aoten-gimpo (new Japanese anme)

Crest present on head; no nuchal cirri; forehead definitely projecting beyond vertical from upper lip. Color greenish brown, with 5 , brown narrow longitudinal lines and with blue dots on sides of body; posterior part of body and caudal dotted with black.

Two specimens, 85 and $97 \mathrm{~mm}$ long respectively, from Takarajima.

The species has hitherto been recorded from the regions from Philippines to India and Samoa. New to Japan.

I. periophthalmus (Cuvier \& VALENCIENnES) Ami-gimpo

Color yellowish brown; anal light brownish, becoming blackish marginally; upper half of caudal whitish, lower half dusky.

Three specimens, 103-122 mm long, from Takarajima.

Distributed in the waters from Okinawa to India, Micronesia, Melanesia, Polynesia and Hawaii.

I. sp.

No crest on head; anterior profile of snout nearly vertical. Color yellowish gray, with more or less bluish wash; head without markings; vertical fins with brownish spots; pectorals white with 3 rows of minute dots.

Two specimens, 64 and $95 \mathrm{~mm}$ long respectively, from Takarajima.

It seems to me to be identified with I. bilitonensis BLEEKER.

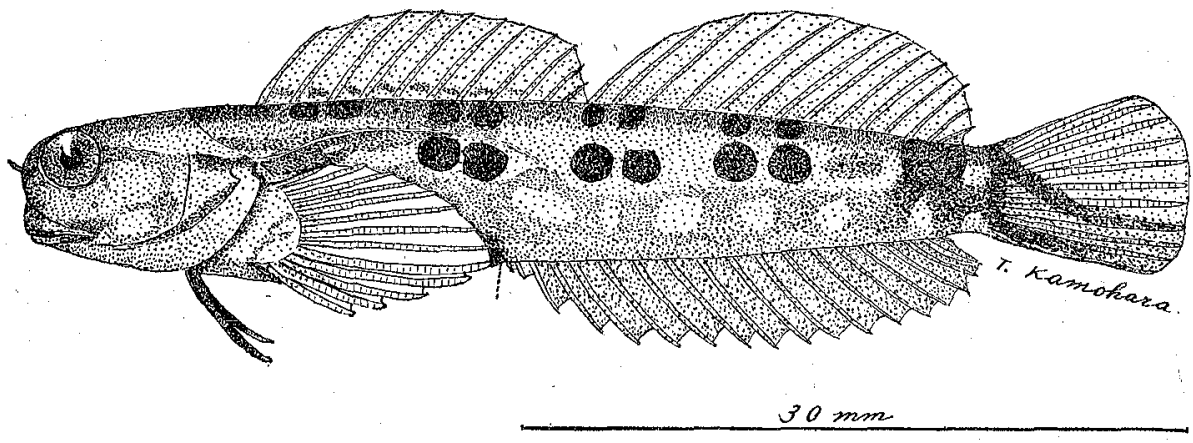

Fig. 17. Istiblennius sp: ??

I. sp. ?? (Fig. 17)

D. XI, 14 ; A. 19 ; P. 13; V. I, 2. Head 3.9 in length without caudal; depth 5.4 ; eye 4 in head; snout 14.7 ; interorbital 6.3 ; depth of caudal peduncle 3 . No crest on head; nasal cirrus simple, equal in length to half eye-diameter. No supraorbital nor nuchal cirri. Anterior profile of snout nearly vertical; eyes large, located in upper, anterior part of head. Mouth inferior, horizontal, lower jaw somewhat shorter than upper; each lip smooth, not crenulate; teeth in a single row in each jaw, minute, 
slender, close-set, loosely embedded in the fleshy gums; no canines.

Dorsals separated by a deep notch; highest spine 2.1 in head, rays longer than the spines, 1.6 in head; membrane of anal incised between the rays, leaving their tips free, the longest 2 in head; neither dorsal nor anal attached to caudal by membrane; pectoral acutely rounded, slightly shorter than head, the membrane incised between lower 5 rays which are somewhat enlarged; ventrals 2 in head; caudal subtruncate, equal in length to pectoral. Head and body naked; lateral line extending above pectoral and ending shortly beyond tip of depressed fin.

Color reddish brown; upper side of body with a double row of rounded blackish blotches, as large as eye; below last rays of dorsal a large saddle-like black blotch. Ventral blackish; anal dusky; caudal with an oblique blackish band from base of upper rays; base of caudal blackish; along lower edge of caudal a blackish band submarginally.

One specimen, $53 \mathrm{~mm}$ long, from Takarajima. Probably new to science.

Rhadoblennius ellipes (JoRDAN \& STARKS) Rōsoku-gimpo

Several specimens, 50-66 mm long, from both islands.

The species is known in the regions from Prov. Tosa to Okinawa.

Entomacrodus striatus (QUOY \& GAIMARD) Suji-gimpo (new Japanese name)

No crest on head. Color reddish yellow, marbled with purple and dotted with violet; a blackish transverse bar behind eye; fins yellowish.

Several specimens, 55-95 mm long, from Nakanoshima.

This species is widely distributed in the seas from Japan (locality not clear) to Mauritius, Micronesia, Melanesia and Polynesia.

E. sp.?

No crest on head; front profile of snout nearly vertical. Color dusky brown, side of body with several dark longitudinal lines and irregularly formed large dark blotches. Dorsal with oblique blackish streaks; anal with a dark longitudinal band basally; caudal with 3 dark crossbands.

Three specimens, $85-125 \mathrm{~mm}$ long, from Nakanoshima.

It seems to me to be identified with E. decussatus (BLEEKER).

E. sp.?

No trace of crest on head. Color reddish yellow; side of body with about 10 saddle-like faint reddish brown blotches; a sharply defined violet patch, slightly larger than eye, above pectoral base. Caudal crossed by 4 dark bands. In the male, anal dusky with tips of rays sharply black; in the female, anal lighter.

Five specimens, 54-67 mm long, from Nakanoshima.

It seems to be referable to E. caudofasciatus (REGAN). 